\title{
Un disegno più vasto. Linguaggi, distanze \& psicologie
}

\author{
Emanuela Chiavoni \\ Sara Colaceci \\ Federico Rebecchini
}

\section{Abstract}

II contributo analizza i percorsi delle tre principali metropolitane di Roma con l'obiettivo di rappresentarne in modo semplificato le valenze culturali fondamentali per il loro riconoscimento all'interno della città.

La conoscenza di questi non luoghi, spazi costruiti per un fine ben specifico di trasporto e transito, non può prescindere dal rapporto che viene a crearsi fra gli individui che li frequentano e deve essere affrontata prendendo in esame sia gli aspetti tangibili che intangibili ai quali rimandano. II termine non luogo, introdotto nel 1992 dall'antropologo francese Marc Augé riguarda gli spazi in cui numerosi individui si incrociano velocemente senza entrare in relazione, spinti dal desiderio di accelerare le tappe quotidiane. I non luoghi sono spazi che si concentrano sul presente e sono significativi della nostra epoca contraddistinta dalla precarietà, dalla provvisorietà, dal passaggio e, anche, da un forte individualismo.

La ricerca madre di riferimento dello studio, tuttora in via di svolgimento, affronta numerose tematiche relative all'argomento ma questo contributo si concentra principalmente sulla conoscenza degli accessi alla metropolitana romana e sul problema che riguarda il loro riconoscimento urbano attraverso sperimentazioni grafiche di disegno e rappresentazione visuale.

Il disegno contribuisce all'orientamento e partecipa ai processi di valorizzazione della città; la comprensione del sistema di trasporto della metropolitana, da parte dei fruitori, siano essi cittadini o turisti, deve essere semplice ed espressa con sensibilità e chiarezza.

L'obiettivo è quello di esplorare linguaggi e rappresentazioni semplificate che possano essere colte rapidamente e a livello intuitivo.

Parole chiave

metropolitana di Roma, visualizzazione, ingressi, disegno, psicologie.
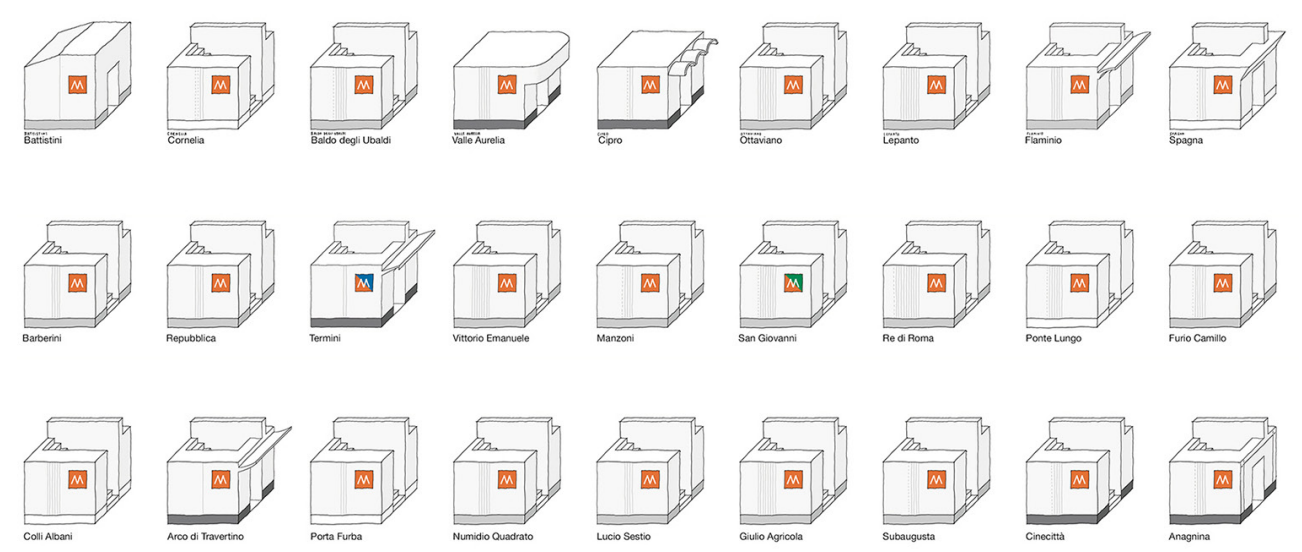


\section{Introduzione}

La ricerca parte dalla richiesta di una convenzione di collaborazione culturale e scientifica tra la Sovrintendenza Capitolina e l'Università di Roma, finalizzata allo studio di una delle fermate centrali più note della linea B; la fermata Circo Massimo. L'analisi da svolgersi attraverso il rilevamento affronta sia il rapporto dell'accesso ai treni della metropolitana con il contesto urbano esterno, sia lo spazio interno, compresa anche la parte dei binari. La fermata della metropolitana si trova tra il Circo Massimo e il Palatino, tra le Terme di Caracalla e il Colosseo ed è addossata a un'architettura moderna che è l'edificio dell'Organizzazione delle Nazioni Unite per l'Alimentazione e l'Agricoltura (FAO_I 952 archh. Cafiero e Ridolfi): la sua localizzazione offre quindi notevoli spunti di riflessione che, all'esterno, riguardano soprattutto una realtà urbana caratterizzata da sovrapposizioni di architetture storiche nel tempo. L'analisi dello spazio interno invece segue un processo diverso in quanto, in genere, lo spazio sotterraneo è costituito da volumetrie comprensibili e rigore quasi geometrico dell'articolazione dei corridoi, passaggi, scale e ascensori. Questo spazio generalmente stimola memorie sensoriali e può essere configurato come luogo di protezione dove la luce è fioca, dove nessun fenomeno atmosferico crea disturbo (sole, pioggia o vento), dove l'individuo si sente sicuro delimitato dalle pareti. Al contrario l'interno della metropolitana può essere vissuto come luogo dove possono manifestarsi sensazioni negative di imprigionamento e compressione della libertà che diventa necessariamente limitata.

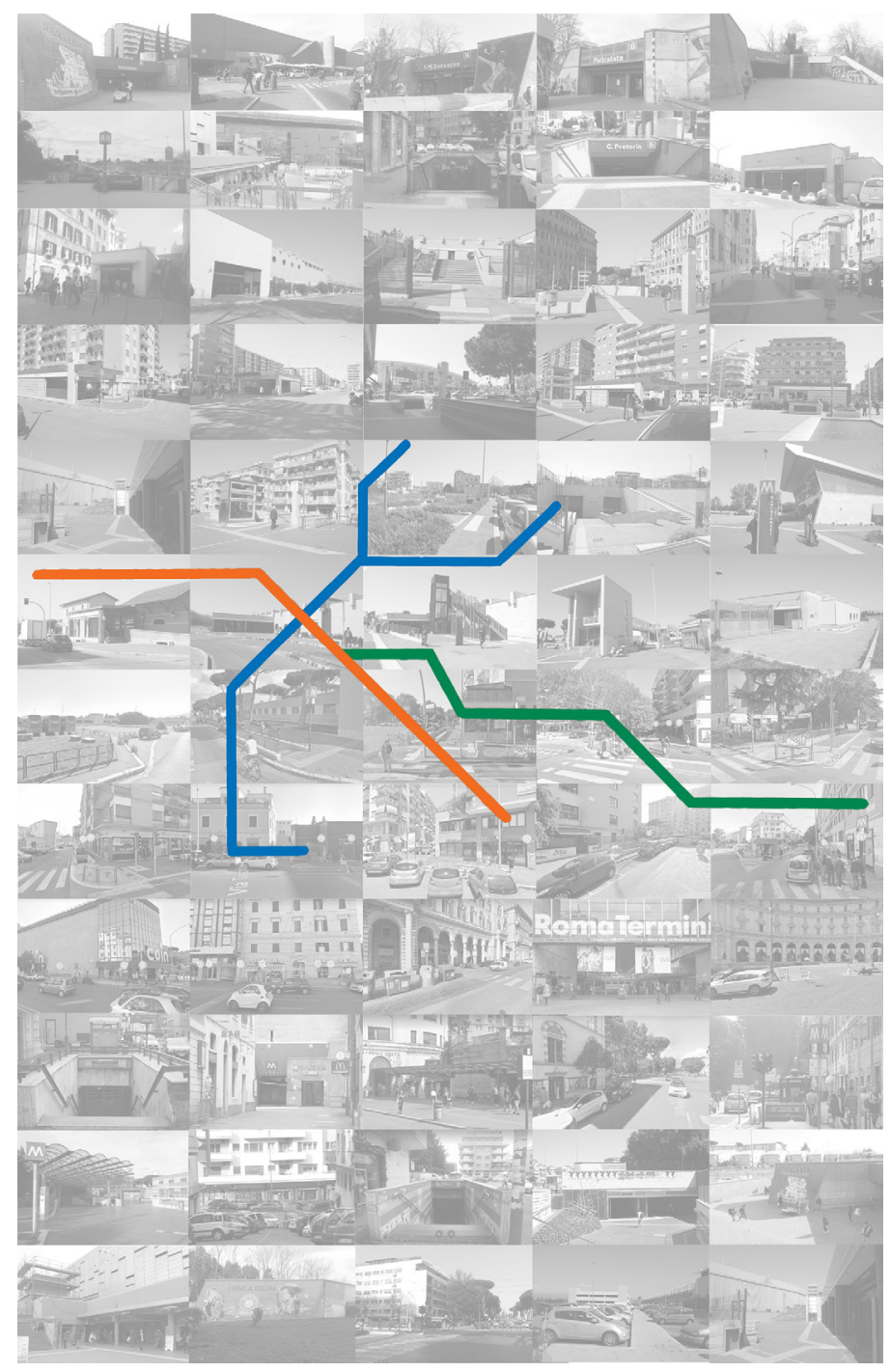


II cittadino spesso si lascia andare al mezzo di trasporto che usa, soprattutto se l'uso è quotidiano, perdendo provvisoriamente la memoria e i riferimenti urbani a causa della deprivazione sensoriale che favorisce una regressione a uno stato mentale non strutturato; per qualcuno questo può essere piacevole (magari si addormenta), per altri invece spiacevole (agitazione e/o ansia) [Fachinelli 1983, p. 24].

Gli ingressi ai treni della metropolitana sotterranei a loro volta sono punti nodali non solo perché visibili nel contesto ma anche perché quando si passa da un luogo aperto conosciuto a uno chiuso ignoto si possono scatenare reazioni impercettibilmente diverse tra individuo e individuo, tra le cui la più comune è sicuramente lo spaesamento. Sempre gli accessi e le uscite determinano un passaggio tra dentro e fuori che va psicologicamente elaborato per poter progettare, costruire e valorizzare al meglio i suddetti accessi.

Mettere una particolare cura nella progettazione degli ingressi, curare quindi il confine, l'inserimento per ridurre l'effetto di spaesamento, di meccanicità e di omologazione [Fachinelli 1988, p. I 13] è uno degli obiettivi che devono darsi gli architetti per poter realizzare architetture sensibili ai bisogni psicologici dell'individuo [Fachinelli I989, p. 49].

Gli ingressi ai binari della metropolitana di Roma sono percettivamente segni forti, permanenti, che devono necessariamente essere visibili nella città cercando sempre di mantenere un rispetto per il tessuto urbano storico. Differenziare una metropolitana dall'altra è fondamentale non solo perché ognuna di esse si trova in aree diverse della città (periferia o centro storico) ma anche per rendere armonico il rapporto degli ingressi con il relativo contesto urbano.

In alcune metropolitane europee sono stati fatti interventi di riqualificazione che hanno reso riconoscibili le identità culturali di ciascuna area nella quale sorge l'accesso alla metro; ad esempio, è stato previsto l'inserimento di mosaici, di raffigurazioni artistiche e/o pezzi scultorei lungo i binari o gli spazi interni, anche per mantenere il collegamento degli elementi artistici in superficie. Questo consente di continuare ad avere un rapporto-soggettivazione

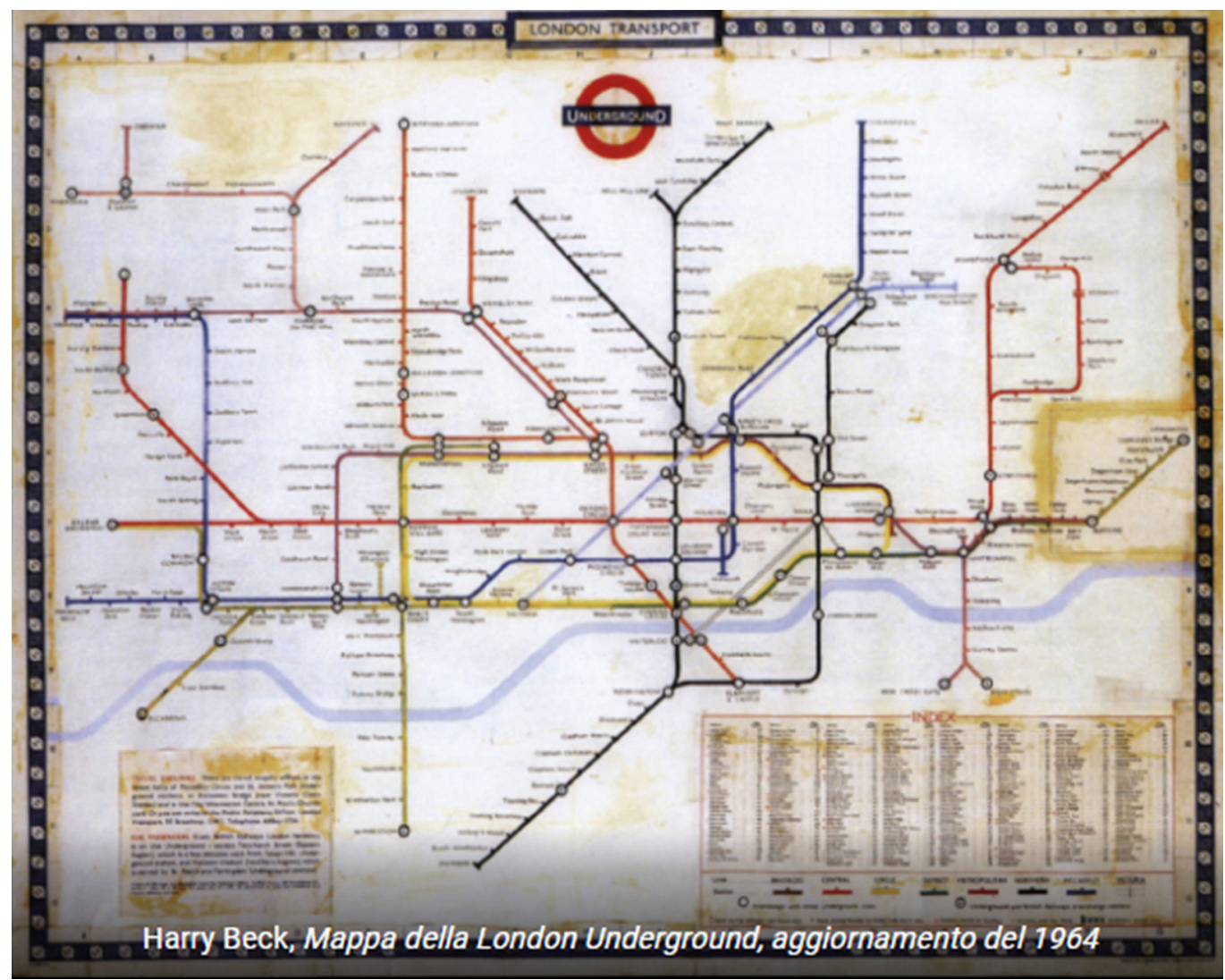


anche di questi spazi, non luoghi [Augé 2009, p. 32], finalizzato, soprattutto, a renderli meno anonimi e ad aumentare le possibilità di sviluppo, soprattutto in una città come Roma dove molti dei fruitori sono turisti in visita.

Dalla lettura critica svolta indagando i numerosi ingressi alle metropolitane romane, che sono rappresentazioni a tutti gli effetti sociali oltre che costruttive/architettoniche, ci si è resi conto che le scelte progettuali che hanno portato alle definizioni dei singoli progetti e alla realizzazione dei singoli volumi architettonici hanno a volte messo in evidenza il rapporto tra esterno/fuori e interno/dentro mentre, in altri casi, questa relazione è stata completamente annullata. In alcuni casi specifici le scelte hanno declinato una continuità con il contesto urbano e, in altri, al contrario, una forte discontinuità.

Fig. 3. Esempi di schedatura e catalogazione delle nformazioni descrittive e grafiche degli accessi metropolitana B di Roma.
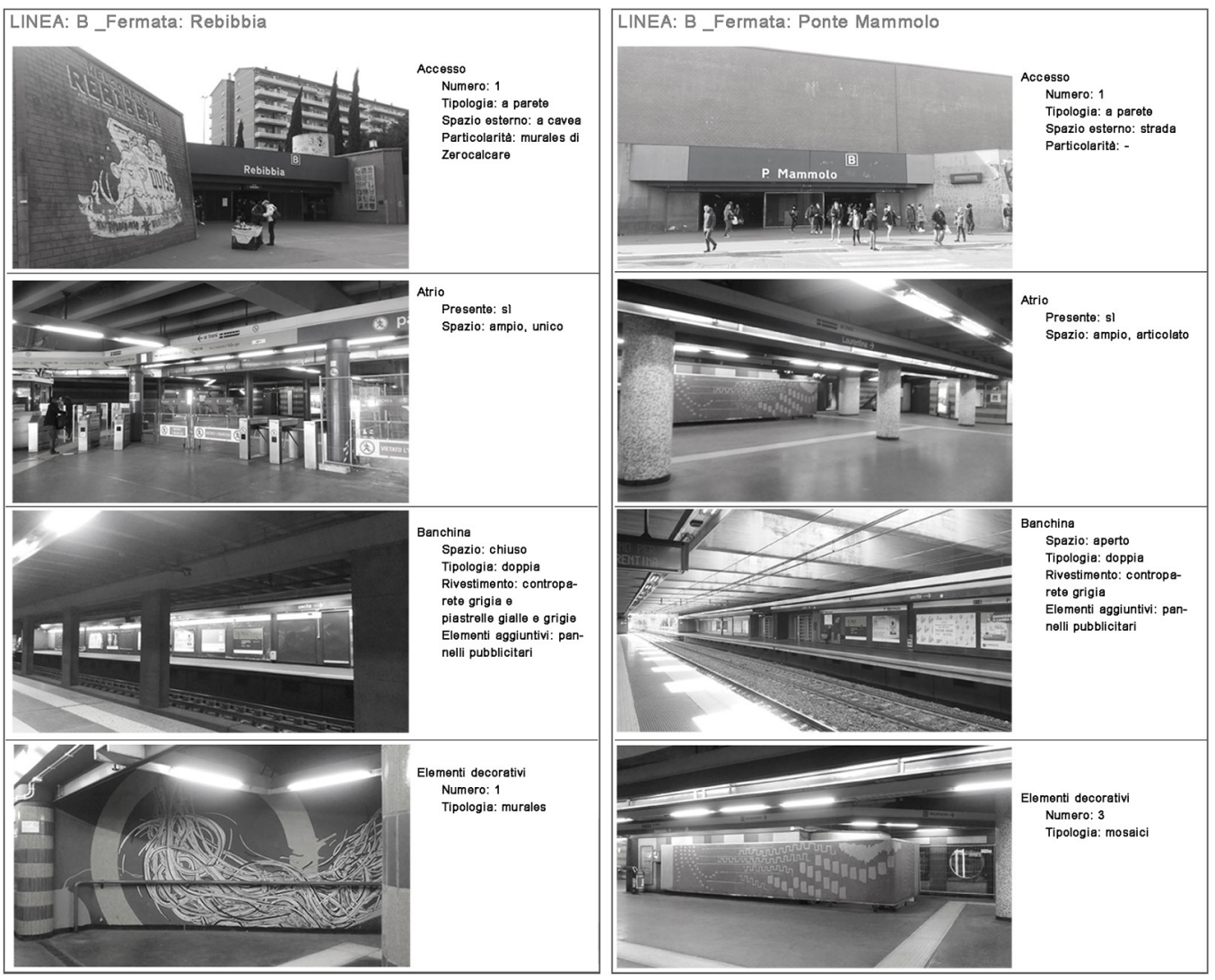

\section{Il disegno più vasto}

La sperimentazione ha previsto modi per rappresentare le informazioni riguardanti l'utilizzo degli spazi accessibili a un pubblico ampio e differenziato tramite visioni panoramiche, sintesi grafiche; la ricerca di una rappresentazione visuale velocemente comprensibile utile per orientare su elementi e caratteristiche formali, strutturali e geometrico-spaziali degli ingressi della metropolitana.

Storicamente il Disegno dell'Informazione attribuito al disegnatore inglese Harry Beck (fig. 2) fu uno dei primi esempi di visualizzazione grafica fatta per la metropolitana di Londra; nel 193 I egli realizzò il primo schizzo della mappa per tale metropolitana e, partendo dal presupposto che le mappe fino ad allora erano state troppo dettagliate per permettere una rapida comprensione della rete, progettò una mappa semplificata, facilmente e intuitivamente riconoscibile da un pubblico più ampio. L'uso di schemi con diagrammi lineari, linee rette semplificate, collegamenti geometrici e colori segnarono il successo di tale rappresentazione grafica (Mappa della London Underground). 


\section{Metodologia}

La fase di conoscenza diretta è avvenuta attraverso sopralluoghi nelle fermate delle metropolitane delle linee A, B, BI, C, con lo scopo di individuare e registrare le caratteristiche formali e spaziali degli accessi attraverso veloci schemi grafici e disegni di rilevamento a vista. Grazie a tali sopralluoghi si è potuto constatare una eterogeneità architettonica degli accessi, sia tra linee differenti e sia all'interno della medesima linea. Sono emerse una varietà e una diversità riguardante la tipologia, lo stile, la dimensione e la valenza nel tessuto urbano.

Per tali ragioni è seguita una attività di schedatura e di catalogazione che ha messo a sistema le specificità, le variazioni e le somiglianze di ogni singolo accesso costituita da criteri di catalogazione, fotografie e schemi grafici (fig. 3). Ciascuna scheda, dunque, include differenti informazioni circa l'accesso: l'informazione descrittiva-testuale, l'informazione visiva-realistica, l'informazione grafica-interpretativa.

La fase successiva si è focalizzata su un processo progettuale-compositivo per contenere nel Disegno l'insieme delle Informazioni raccolte (fig. 4), tentando di condurre un atto creativo di ideazione della forma a partire da dati oggettivi riguardanti uno spazio architettonico-urbano [Cervellini 2012, p. 57].

Fig. 4. Disegni di studio relativi alla fase di progettazione della forma
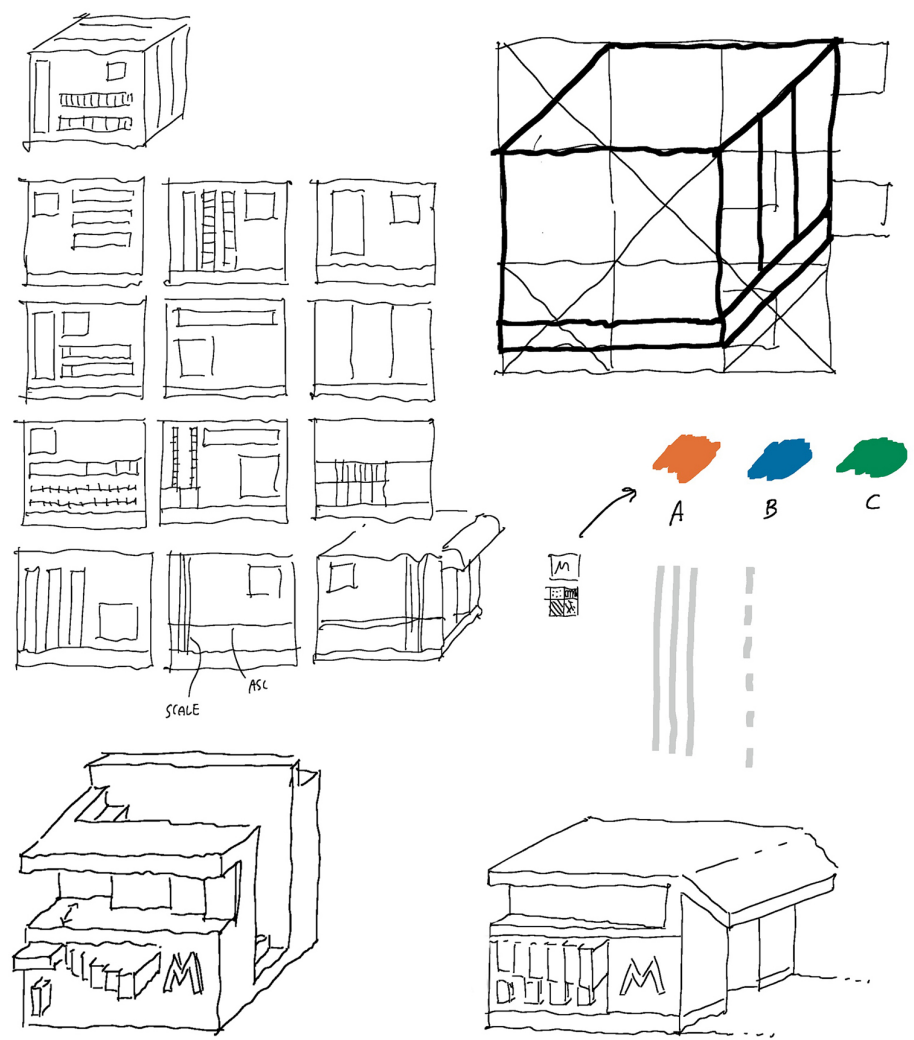

I parametri selezionati sono stati: la linea; la tipologia di accesso (a seconda se questo ha luogo nella parete o nel pavimento); il tipo di costruzione (a seconda se sia ad hoc per la metropolitana, oppure da riconversione oppure inserita nel tessuto urbano); le modalità di accesso tramite scala, scale mobili, ascensore o montacarichi per disabili; la visibilità; il contesto; lo stato di conservazione e i materiali.

Tali informazioni sono state tradotte in un alfabeto di segni tramite un processo di astrazione intellettivo finalizzato a una elaborazione grafica sulla composizione della forma (fig. 5), Questa è stata sperimentata tramite la manipolazione del cubo quale elemento geometrico tridimensionale elementare. 

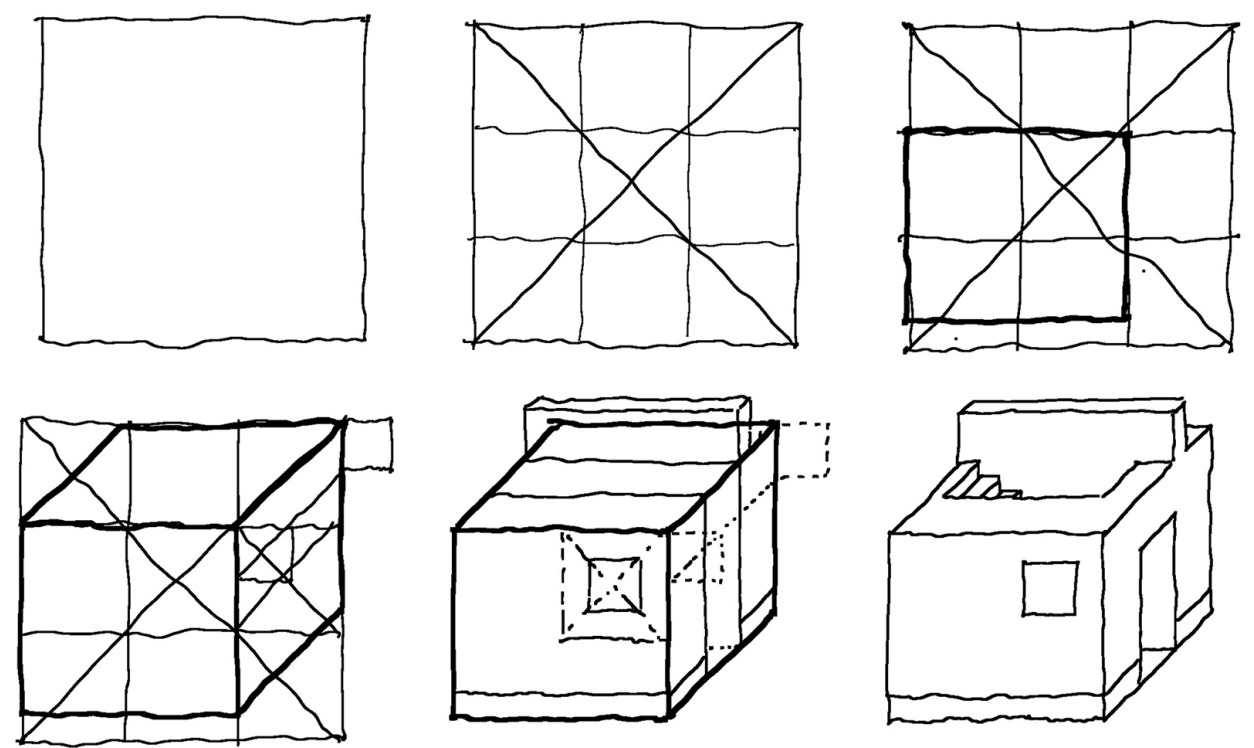

Fig. 6. Legenda esplicativa delle parti del cubo.
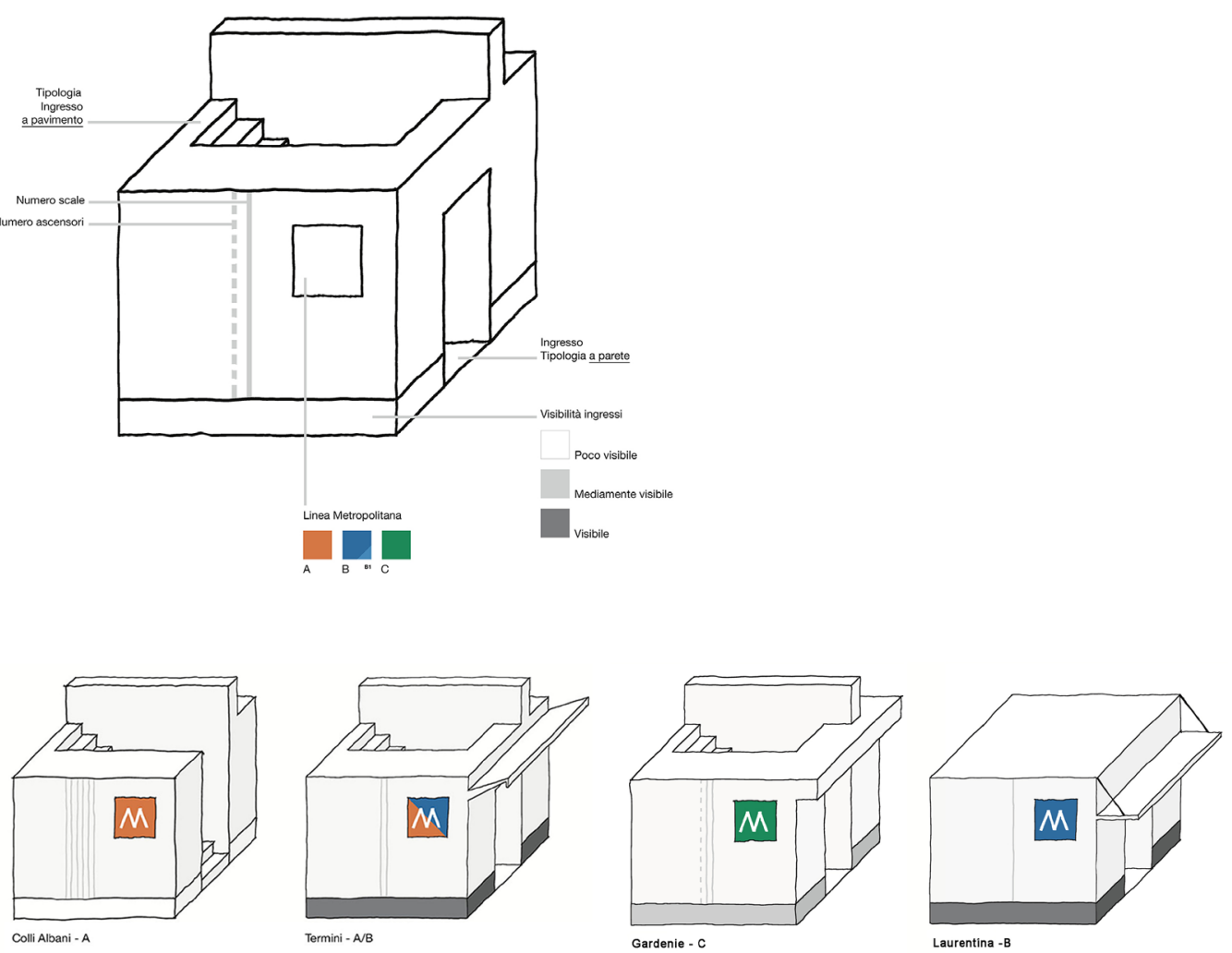

Fig. 7. Esempio di

all'accesso delle fermate all'accesso delle fermate Castro Pretorio, Teano.

Fig. 8. Esempio di composizione relativa all'accesso delle fermate
Gardenie, Laurentina, San Giovanni, Cipro.
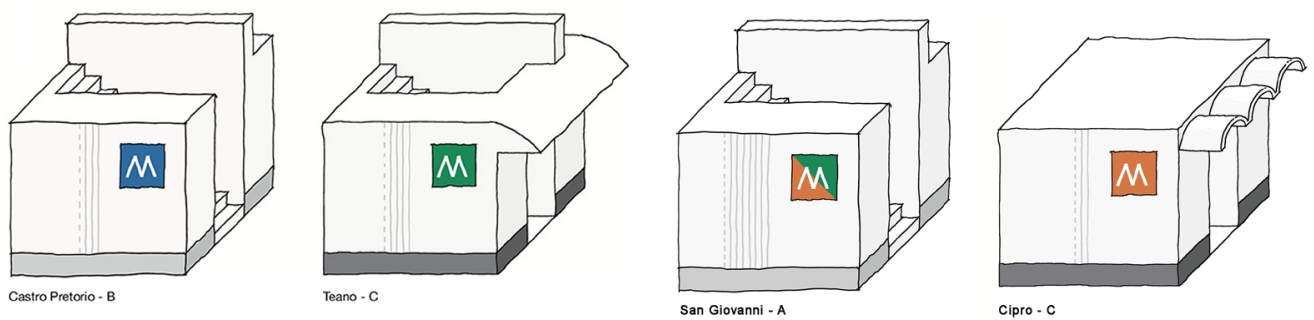
Fig. 9. Giorgia Lupi, The Digital in Architecture. Immagine tratta da: <wnw.giorgialupi.com> 2020)
In sintesi, l'approccio metodologico si è sviluppato in due direzioni: la prima è stata un'attività conoscitivo-analitica, la quale ha previsto la conoscenza diretta e la schedatura delle peculiarità degli accessi in informazioni utili; la seconda è stata un'attività creativa e di sintesi interpretativa, la quale si è concentrata su un iter progettuale mirato alla trasposizione delle molteplici informazioni (descrittive-testuali, visive, grafiche-interpretative) in un'unica immagine grafica concepita in maniera da includere informazioni plurime.

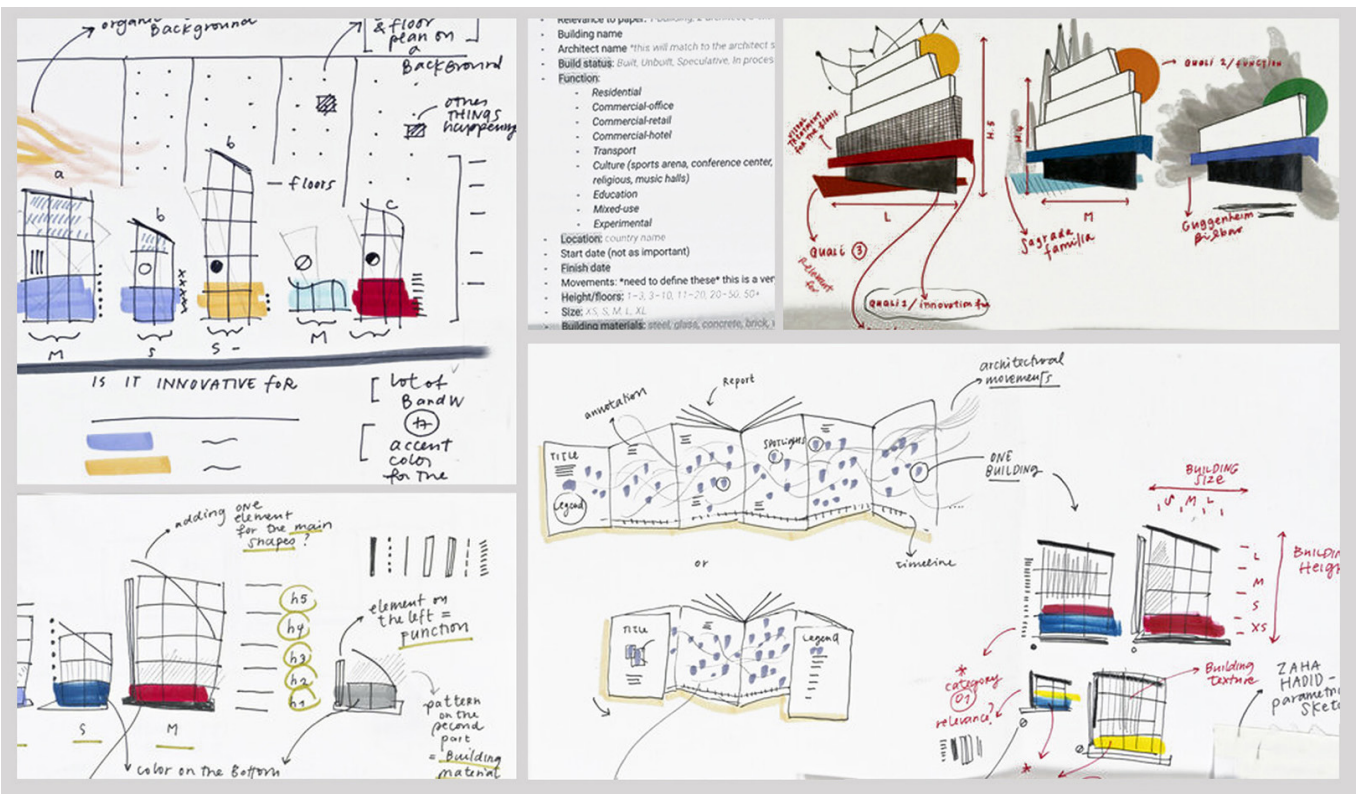

\section{Sperimentazione}

In tale esperienza si ha un disegno che parte da informazioni reali e poi si tramuta in un disegno di invenzione della forma, le cui parti hanno una relazione affine con la realtà. Tale disegno oscilla tra due poli opposti: uno, iniziale, che è legato alle informazioni della realtà oggettiva e l'altro, successivo, che è legato all'immaginario.

Si riflette sulla funzione sperimentale ed esplorativa del Disegno, attraverso cui si ragiona in un continuo percorso di ricerca grafica ed espressiva [lppoliti 2017, p. I45].

II Disegno prevede declinazioni di infinite possibilità grafiche che, lette nella loro interezza, individuano un testo narrativo.

La manipolazione della forma-cubo, a partire da una griglia regolare, si avvale di reiterazioni e di variazioni. Si tratta di una operazione che avanza per prove, per tentativi, per esperimenti e per giustapposizioni. Essa ha una connotazione processuale e costruttiva [Purini 2010, p. 12].

Le immagini in sequenza variano di poco, di quella variazione così minima che, tuttavia, le rende uniche e diverse, quindi l'invenzione della forma procede con un lavoro sullo scarto e sulla discordanza.

La composizione grafica, pur basandosi sulla libertà espressiva mantenendo un livello di astrazione, è stata condotta tramite una matrice conformativa che ha generato una gamma di configurazioni.

II processo di morfogenesi è iniziato da una griglia geometrica regolare per individuare superfici e volume del cubo (fig. 6). La geometrizzazione è finalizzata al controllo delle parti che sottostanno alla composizione interna all'iter progettuale.

L'itinerario creativo è costruito sull'ideazione e sulla regola, sull'invenzione e la trasgressione, strutturando la forma di volta in volta a seconda delle informazioni che essa deve manife- 
stare [Cervellini 2020, p. 204]. La composizione ha incorporato in sé i parametri selezionati in precedenza.

La tipologia dell'accesso è stata individuata con un'azione plastica nel cubo (scala per l'accesso a pavimento e apertura verticale per l'accesso a parete). Gli altri dati sono stati definiti sulle superfici del cubo. La linea è esplicitata attraverso il simbolo $M$ con il relativo colore ufficiale di appartenenza. II numero di scale e ascensori è stato specificato attraverso delle linee verticali continue e tratteggiate, mentre la maggiore o minore visibilità è stata precisata tramite una fascia con toni di grigio differenti. Un elemento volumetrico aggiuntivo al cubo identifica la presenza o meno di una pensilina esterna (figg. 7, 8).

Questo lavoro di sintesi di informazioni, spesso in sovrapposizione, ha portato a degli oggetti tridimensionali che solo vagamente vogliono ricordare un'architettura. Si è partiti da un riferimento importante come The Digital in Architecture di Giorgia Lupi (fig. 9), un lavoro in cui i dati relativi a edifici strettamente legati al digitale sono rimodellati in proto-prospetti di architetture, dimostrando come sia possibile attuare elaborazioni grafiche in cui il disegno e i dati sono strettamente connessi [Lupi, Posavec 20 I 6; Lupi, Posavec 20 I0].

Oggetti bidimensionali, quindi, decisamente più facili da controllare rispetto a una terza dimensione. Anche nei bozzetti di studio della Lupi si vede che l'idea di tridimensionalità è poi abbandonata. Prendendoli come esempio, si è lavorato sul discretizzare i dati raccolti nei sopralluoghi per inserirli all'interno di un volume che avesse una sua coerenza ma senza una eccessiva complessità. L'obiettivo infatti era quello di arrivare a un 'disegno vasto'.

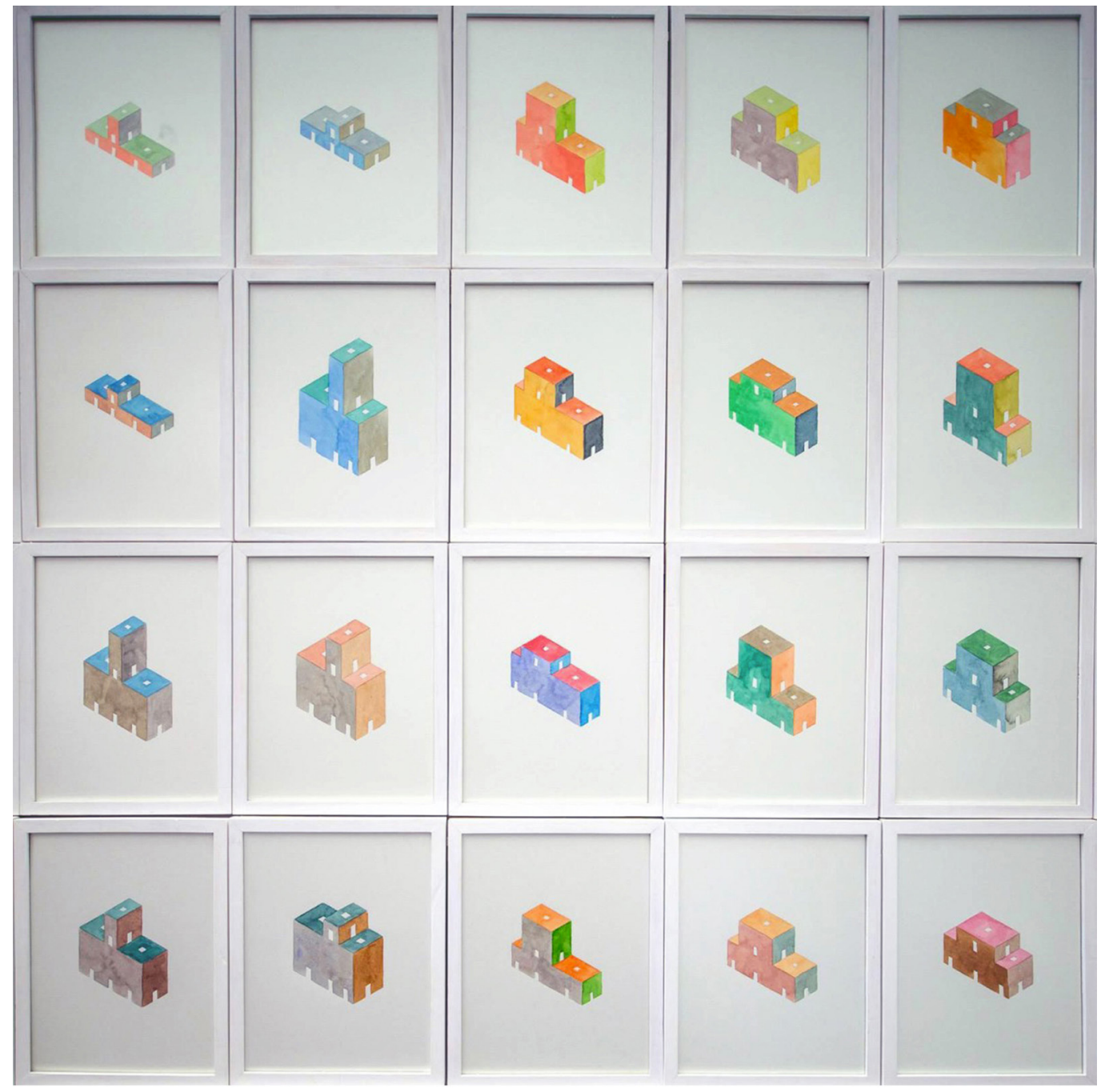




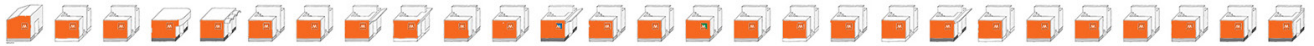 MA

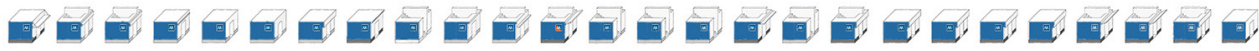 \\ MB

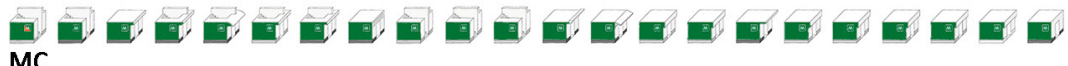

Rifacendosi allo splendido lavoro del duo cileno Pezo Von Ellrichshausen per la Biennale di Chicago (fig. I0), si è cercato di comporre l'insieme dei volumi, dalle minime e fondamentali variazioni, all'interno di una composizione il più vasta e regolare possibile. In questo modo si è potuto abbracciare una mole di dati non indifferenti, offrendo sia un quadro d'insieme coerente e comprensibile, ma anche una immagine che è possibile interrogare e consultare scendendo nel dettaglio.

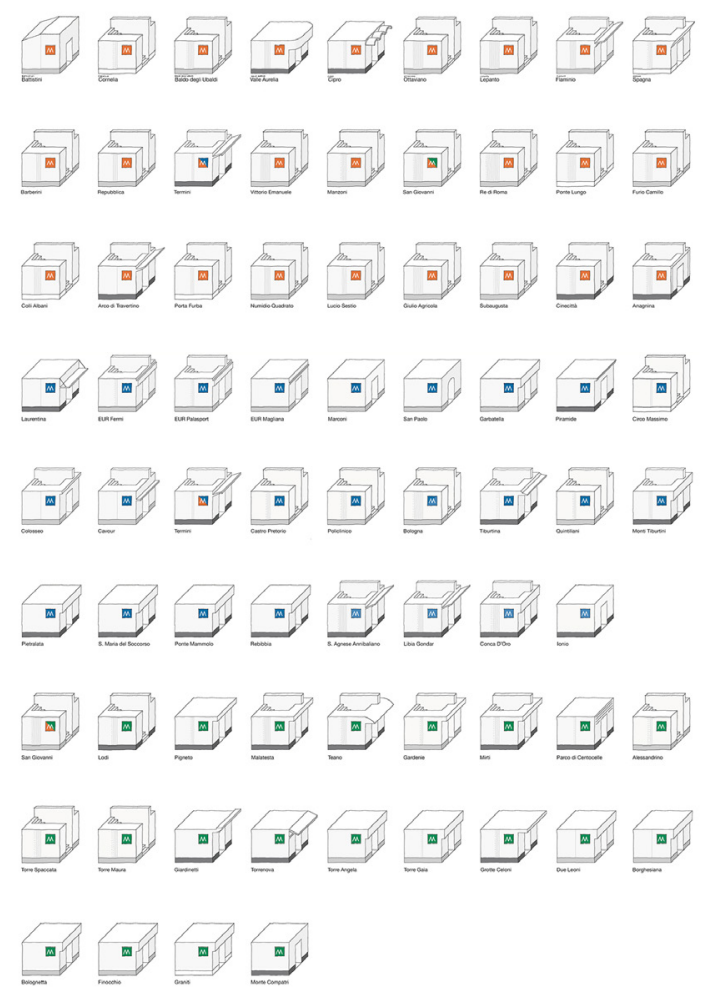

\section{Conclusioni}

Di fronte a questa serie di piccoli volumi atti a raffigurare gli accessi della Metropolitana di Roma, l'occhio può abbracciare l'insieme o perdersi all'interno delle numerose varianti. Abbracciando l'insieme si ha subito una percezione che permette di cogliere alcune situazioni lampanti, come per esempio la quantità di stazioni. Banalmente anche rendersi conto visivamente di quante stazioni della Metro esistono per ogni linea è una informazione che spesso non è ben chiara. Sono ben 73 le stazioni (fig. I I), con solo tre snodi per cambiare linea. Allo stesso tempo, avendo ben in mente la legenda, ci si rende subito conto della scarsa visibilità rispetto alla città che la Metro A possiede se paragonata alle sue due sorelle minori; sicuramente perché metro $\mathrm{B}$ e $\mathrm{C}$ sono di più recente costruzione. 
Se invece ci avviciniamo ai singoli volumi possiamo cogliere altri dettagli, e cioè il tipo di accessi presente in ogni stazione (a parete, a pavimento, o entrambi), ma soprattutto il numero di scale e ascensori che permettono l'accesso alla Metro. Attraverso un veloce lavoro di comparazione ci rendiamo subito conto della quasi assenza di ascensori sulla linea A (al centro di dure polemiche in diversi municipi), ma anche della regolarità di accessi a parete per alcuni tratti della metro $\mathrm{B}$ e $\mathrm{C}$.

Le chiavi di lettura sono molteplici, e i volumi tridimensionali in questo step della ricerca sono nella loro conformazione più elementare. Sarà possibile poi integrare informazioni per avere un quadro d'insieme il più completo possibile.

Questo 'disegno più vasto', quindi, permette di abbracciare informazioni anche divergenti tra loro inquadrandole all'interno di uno schema predefinito, ma allo stesso tempo flessibile. Interfacciarsi con le informazioni e le criticità che la metropolitana di Roma presenta diventa quindi una questione visiva, prima di tutto, con la speranza di una futura adeguazione di ogni accesso alle norme dell'Universal Design, o anche più banalmente a modifiche dei diversi accessi per una fruizione più agevole per cittadini e turisti (fig. 12) [I].

\section{Note}

[I] Pur avendo condiviso la ricerca, Emanuela Chiavoni ha scritto Abstract, Introduzione, II disegno più vasto, Sara Colaceci ha scritto Metodologia e Sperimentazione, Federico Rebecchini ha scritto Sperimentazione e Conclusioni. I disegni sono stati realizzati da Federico Rebecchini.

\section{Riferimenti bibliografici}

Augé M. (2009). Nonluoghi. Introduzione a un'antropologia della surmodernità. Milano: Elèuthera.

Cervellini F. (20I2). I modi del disegno d'invenzione. In Disegnare. Idee immagini, anno XXIII, n. 45, pp. 56-65.

Cervellini F. (2020). II Disegno officina grammaticale della Forma visiva. In G. Aureli, F. Colonnese, S. Cutarelli (a cura di). Intersezioni. Ricerche di Storia, Disegno e Restauro dell'Architettura, pp. 203-2 10. Roma:Artemide.

Fachinelli E. (1983). Claustrofilia. Saggio sull'orologio telepatico in psicoanalisi. Milano: Adelphi.

Fachinelli E. ( 1988). Estasi metropolitane. In M. Manzoni, S. Scalpelli (a cura di). Velocità. Tempo sociale tempo umano. Milano: Guerini e Associati, pp. I13-116.

Fachinelli E. (1989). La mente estatica. Milano: Adelphi.

Ippoliti E. (20 I 7). Rinnovare lo sguardo. II disegno e le sue pratiche: rappresentare, comunicare, narrare. In Diségno, I, pp. I 43 - I 54.

Lupi G., Posavec S. (20 I0). Observe, Collect, Draw! A Visual Journal. Hudson: Princeton Architectural Pr.

Lupi G., Posavec S. (2016). Dear Data. London: Particular Books.

Purini F. (2010). Un quadrato ideale. In Disegnare. Idee Immagini, anno 2 I, n. 40, pp. I2-25.

\section{Sitografia}

<https://www.storiadeldisegnografico.com/2020/03/I7/information-design-i-pionieri/> (consultato il I2 dicembre 2020).

<http://giorgialupi.com> (consultato il 15 dicembre 2020).

<http://densitydesign.org/> (consultato il I 5 dicembre 2020).

<http://www.lbollini.it/> (consultato il I 5 dicembre 2020).

Autori

Emanuela Chiavoni, Sapienza Università di Roma, emanuela.chiavoni@uniromal.it

Sara Colaceci, Sapienza Università di Roma, sara.colaceci@uniromal.it

Federico Rebecchini, Sapienza Università di Roma, federico.rebecchini@uniromal.it

Per citare questo capitolo: Chiavoni Emanuela, Colaceci Sara, Rebecchini Federico (2021). Un disegno più vasto. Linguaggi, distanze \& psicologie/ A Wider Drawing. Languages, Distances \& Psychologies. In Arena A., Arena M., Mediati D., Raffa P. (a cura di). Connettere. Un disegno per annodare e tessere. Linguaggi Distanze Tecnologie. Atti del $42^{\circ}$ Convegno Internazionale dei Docenti delle Discipline della Rappresentazione/Connecting. Drawing for weaving relationship. Languages Distances Technologies. Proceedings of the $42^{\text {th }}$ International Conference of Representation Disciplines Teachers. Milano: FrancoAngeli, pp. 452-471. 


\title{
A Wider Drawing. Languages, Distances \& Psychologies
}

\author{
Emanuela Chiavoni \\ Sara Colaceci \\ Federico Rebecchini
}

Abstract

The contribution analyzes the routes of the three main subways of Rome with the aim of representing in a simplified way the fundamental cultural values for their recognition within the city.

The knowledge of these non-places, spaces built for a specific purpose of transport and transit, cannot ignore the relationship created between the individuals who frequent them and must be addressed by examining both the tangible and intangible aspects to which they refer. The term non-place, introduced in 1992 by the French anthropologist Marc Augé, concerns the spaces in which numerous individuals meet quickly without entering into a relationship, driven by the desire to accelerate the daily stages. Non-places are spaces that focus on the present and are significant in our age characterized by precariousness, provisionality, passage, and strong individualism.

The study's primary research reference, still in progress, addresses numerous issues related to the topic, but this contribution focuses mainly on the knowledge of the accesses to the Roman underground and on the problem that concerns their urban recognition through drawing experiments and visual representations.

The design contributes to orientation and participates in the processes of enhancing the city; the understanding of the underground transport system by the users, be they citizens or tourists, must be simple and expressed with sensitivity and clarity.

The goal is to explore simplified languages and representations that can be grasped quickly and intuitively.

\section{Keywords}

Rome underground, visualization, entrances, drawing, psychologies.
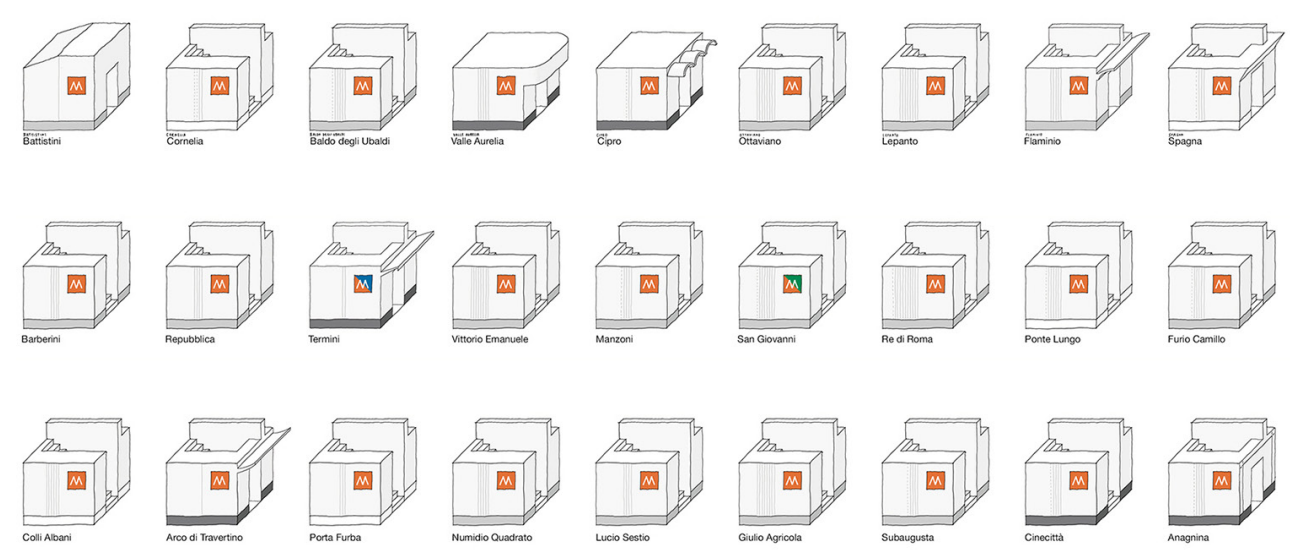


\section{Introduction}

The research starts from the request for a cultural and scientific collaboration agreement between the Capitoline Superintendency and the University of Rome, aimed at studying one of the most famous central stops on line B, the Circo Massimo stop. The analysis, to be carried out through the survey, addresses both the relationship of access to metro trains with the external urban context and the internal space (including the part of the tracks).

The metro stop is located between the Circus Maximus and the Palatine Hill, between the Baths of Caracalla and the Colosseum, and is leaning against a modern architecture which is the building of the United Nations Food and Agriculture Organization (FAO 1952 archh. Cafiero and Ridolfi): its location, therefore, offers considerable food for thought which, on the outside, mainly concern an urban reality characterized by overlapping historical architecture over time. The analysis of the internal space, on the other hand, follows a different process as, in general, the underground space is made up of understandable volumes and almost geometric rigour of the articulation of corridors, passages, stairs and elevators. This space generally stimulates sensory memories and can be configured as a place of protection where the light is dim, where no atmospheric phenomenon creates disturbance (sun, rain or wind), where the individual feels safe delimited by the walls. On the contrary, the interior of the subway can be experienced as a place where negative feelings of imprisonment and compression of freedom (which necessarily becomes limited) can occur.

Citizens often let themselves go to the means of transport they use, especially if they are used

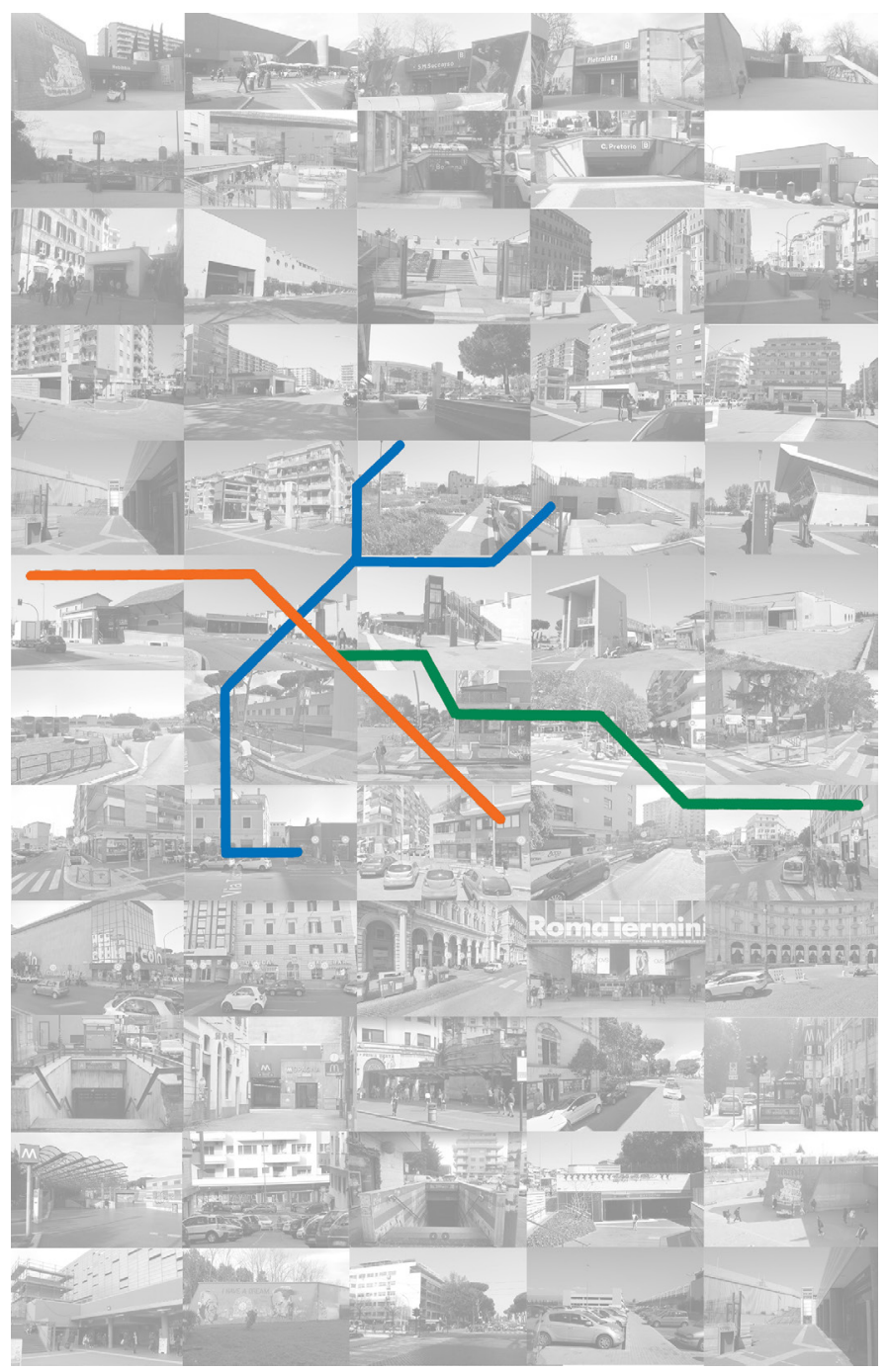


daily, temporarily losing their memory and urban references due to sensory deprivation that favours a regression to an unstructured state of mind; for some, this may be pleasant (perhaps falling asleep), for others unpleasant (agitation and/or anxiety) [Fachinelli 1983, p. 24].

The entrances to underground subway trains are in turn nodal points not only because they are visible in the context but also because when one passes from a known open place to an unknown closed one, imperceptibly different reactions can be triggered between individual and individual, among which the most disorientation is certainly common. The accesses and exits always determine a passage between inside and outside that must be psychologically elaborated in order to be able to design, build and make the most of the aforementioned accesses. Putting particular care in the design of the entrances, therefore taking care of the boundary, an insertion aimed at reducing the effect of disorientation, of mechanical nature and of homologation [Fachinelli 1988, p. I I 3] is one of the objectives that architects must set themselves in order to achieve architectures sensitive to psychological needs of the individual [Fachinelli 1989, p. 49].

The entrances to the tracks of the Rome metro are perceptually strong, permanent signs that must necessarily be visible in the city - possibly trying to maintain a respect for the historical urban fabric.

Differentiating one subway from another is essential not only because each of them is located in different areas of the city (suburbs or historic centre), but also to harmonize the relationship of the entrances with the related urban context.

In some European metros, redevelopment interventions have made recognizable the cultural identities of each area in which the Metro access was located. For example, the insertion of mosaics, artistic representations and/or sculptural pieces along the tracks or interior spaces was envisaged.The objective was also to maintain the connection of the artistic elements with the surface. This allows us to continue to have a relationship-subjectivation of these spaces, not places [Augé 2009, p. 32], aimed, above all, at making them less anonymous. Especially in a city like Rome where many of the users are visiting tourists.

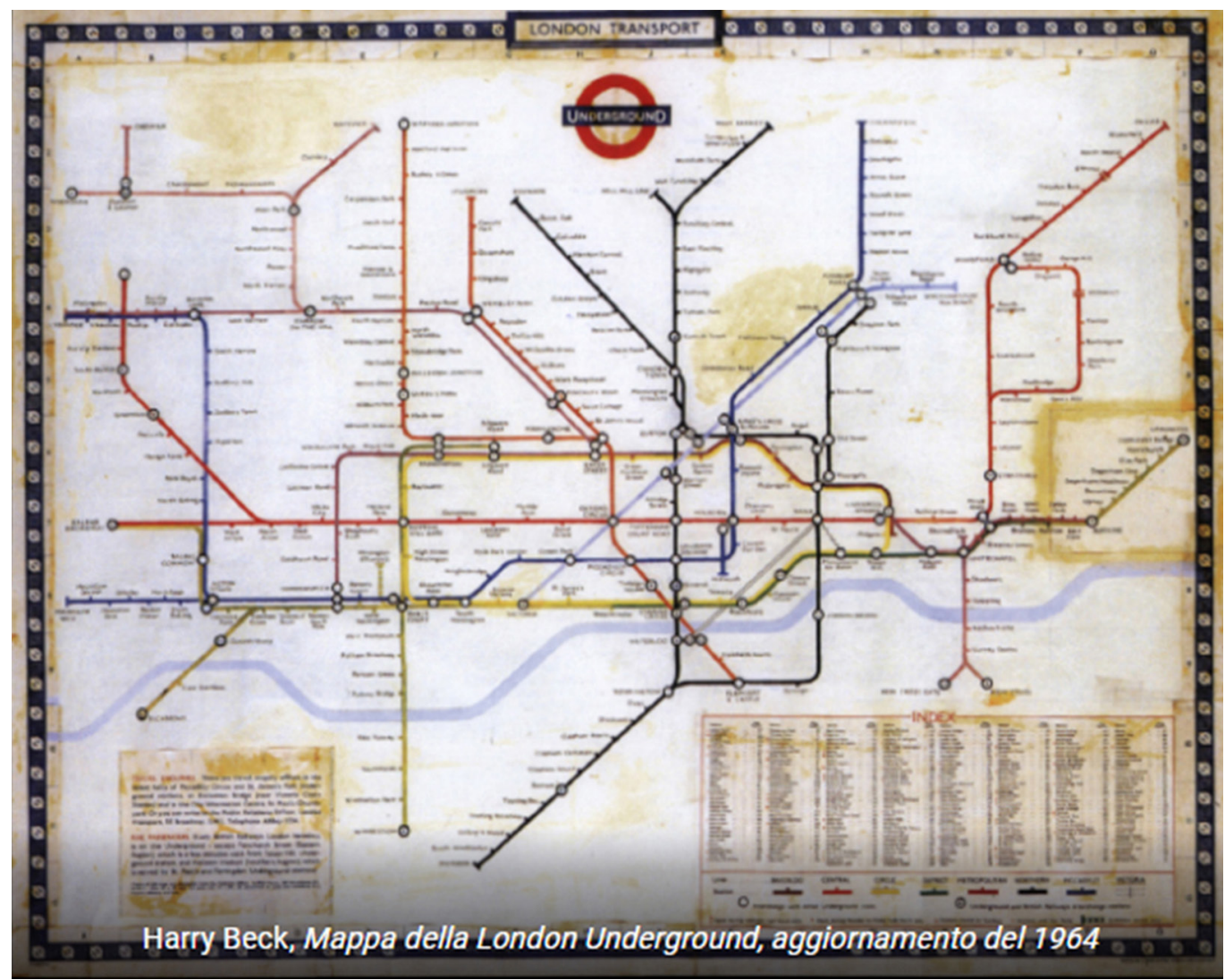




\section{The wider drawing}

The experimentation envisaged ways to represent information regarding the use of spaces accessible to a wide and differentiated public through panoramic visions and graphical summaries. An objective was the development of a quickly understandable visual representation useful for orienting on the formal, structural and geometric-spatial elements and characteristics of the subway entrances.

Historically, the Information Design attributed to the English designer Harry Beck (fig. 2) was one of the first examples of graphic visualization made for the London Underground; in 1931, he made the first sketch of the map for this subway and, assuming that the maps until then had been too detailed to allow a quick understanding of the network, he designed a simplified map, easily and intuitively recognizable by a wider audience. The use of schemes with linear diagrams, simplified straight lines, geometric connections and colors marked the success of this graphic representation (Map of the London Underground.)
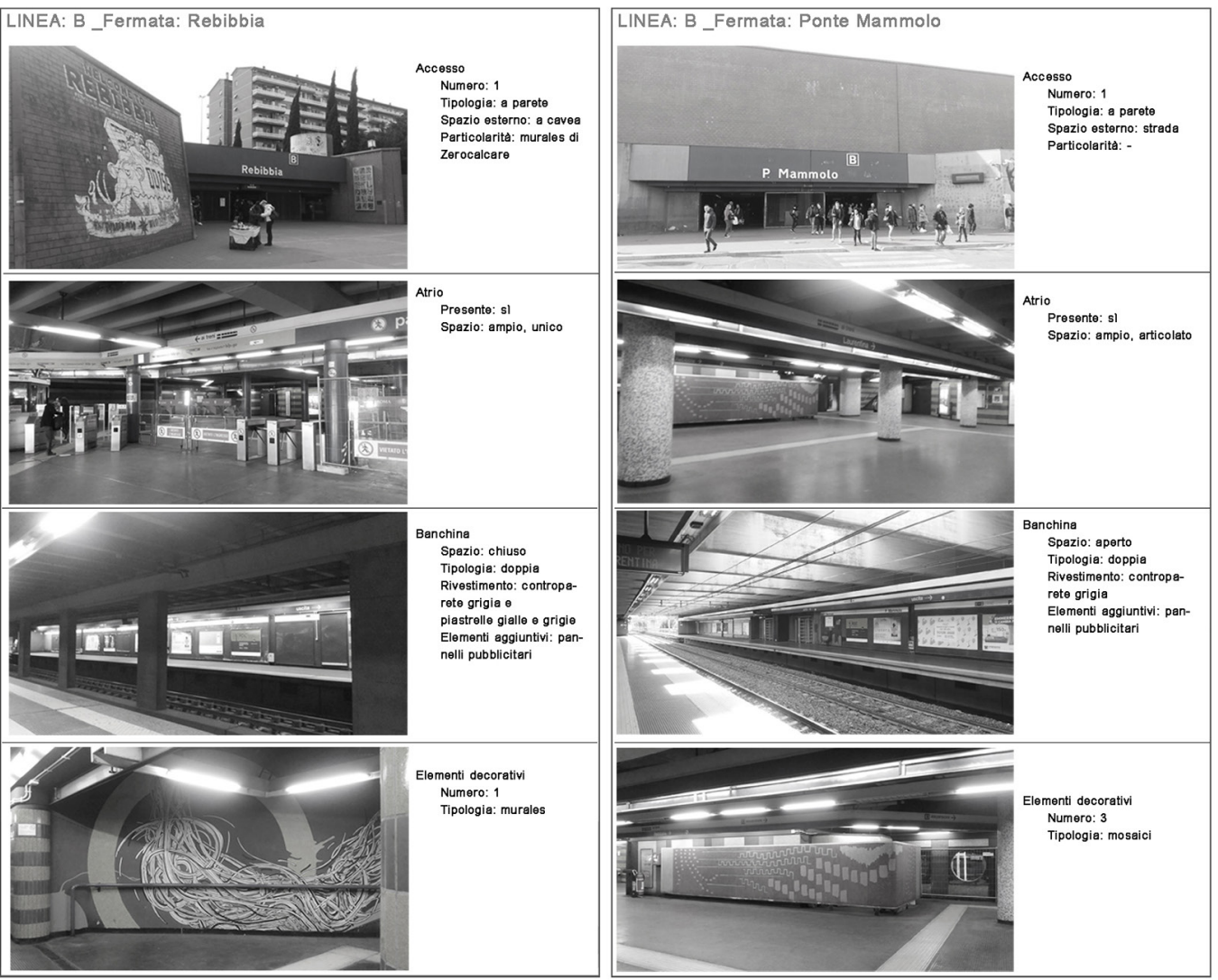

\section{Methodology}

The direct acquaintance phase took place through inspections in the subway stops of lines A, B, B I, C, with the aim of identifying and recording the formal and spatial characteristics of the accesses through quick graphic schemes and survey sketches.

Thanks to these inspections, it was possible to ascertain an architectural heterogeneity of the accesses, both between different metro lines and within the same line. A variety and diversity emerged regarding the typology, style, size and value in the urban fabric.

For these reasons, a filing and cataloguing activity followed, which systematized the specificities, variations and similarities of every single access consisting of cataloguing criteria, photographs and graphic schemes (fig. 3). Each form, therefore, includes different information about access: descriptive-textual information, visual-realistic information, graphic-interpretative information. 
The next phase focused on a design-compositional process to contain the whole of the collected information in the Drawing (fig. 4), attempting to conduct a creative act of designing the form starting from objective data concerning an architectural-urban space [Cervellini 20I2, p. 57].

The selected parameters were: the metro line; the type of access (depending on whether this takes place in the wall or on the floor); the type of construction (depending on whether it is new construction for the underground, or from reconversion or inserted in the urban fabric); the methods of access via stairs, escalators, or lifts; visibility; the context; the state of conservation and the materials.

This information was translated into an alphabet of signs by means of an intellectual abstraction process aimed at a graphic elaboration on the composition of the form (fig. 5). This was experimented through the manipulation of the cube as an elementary three-dimensional geometric element.

In summary, the methodological approach developed in two directions: the first was a cognitive-analytical activity, which involved direct knowledge and the filing of peculiarities of accesses to useful information; the second was a creative and interpretative synthesis activity, which focused on a design process aimed at the transposition of multiple information (descriptive-textual, visual, graphic-interpretative) into a single graphic image conceived to include multiple information.
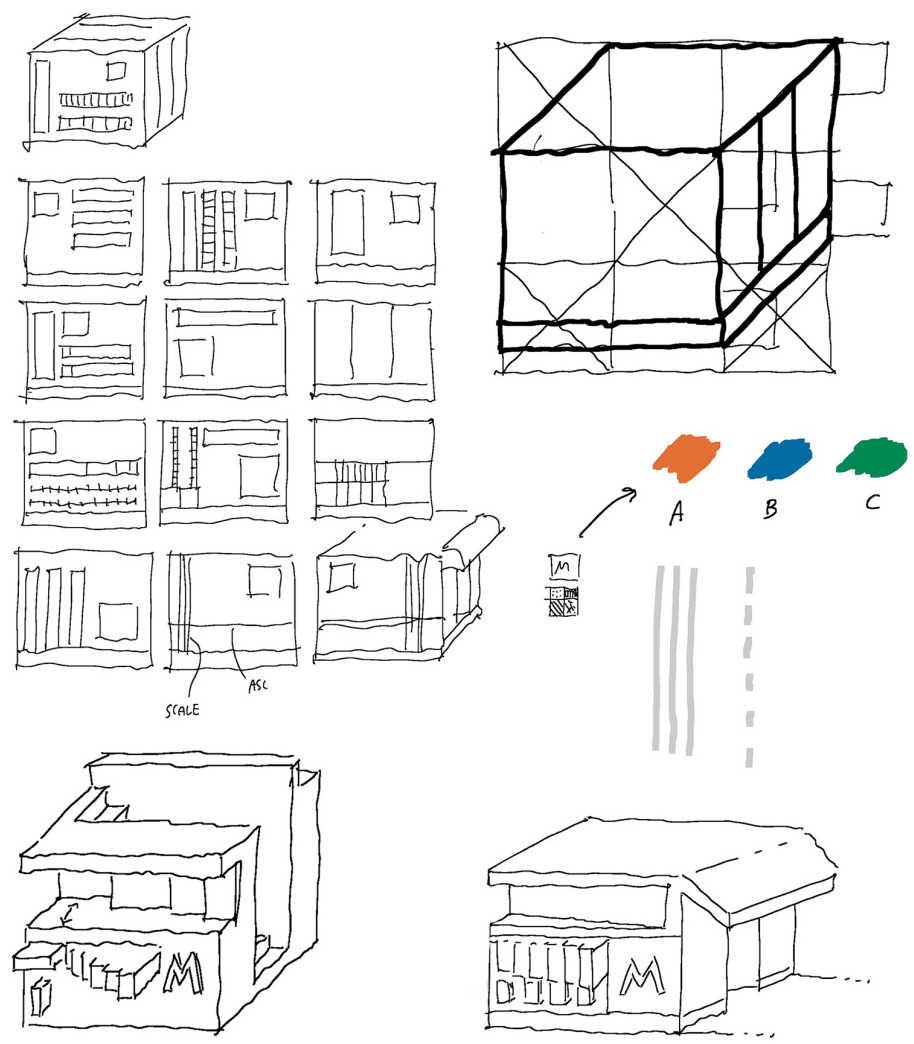

\section{Experimentation}

In this experience, we have a drawing that starts from real information and then turns into a design of invention of the form. This design oscillates between two opposite poles: one, initial, which is linked to the information of objective reality, and the other, subsequent, which is linked to the imaginary.

It reflects on the experimental and exploratory function of Drawing, through which it is possible to analyze different situations, in a continuous path of graphic and expressive research [lppoliti 20 I7, p. 145]. 

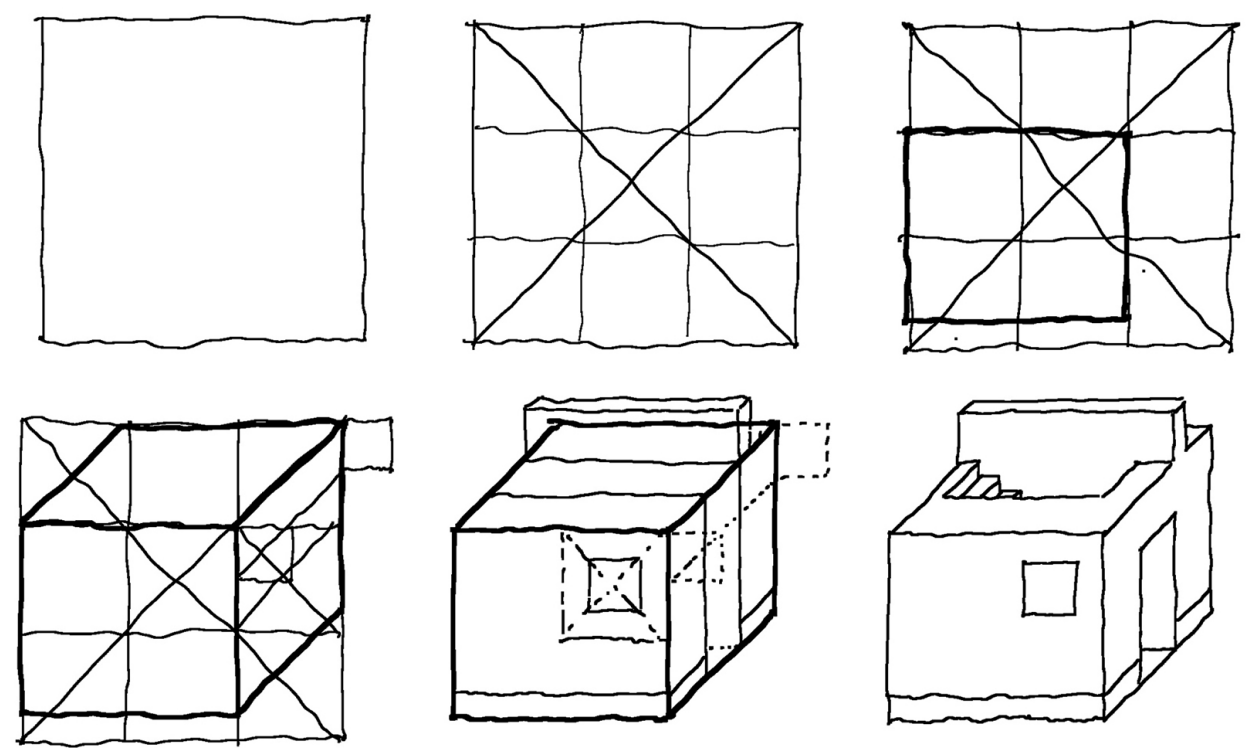

Fig. 6. Process of

rom the square to
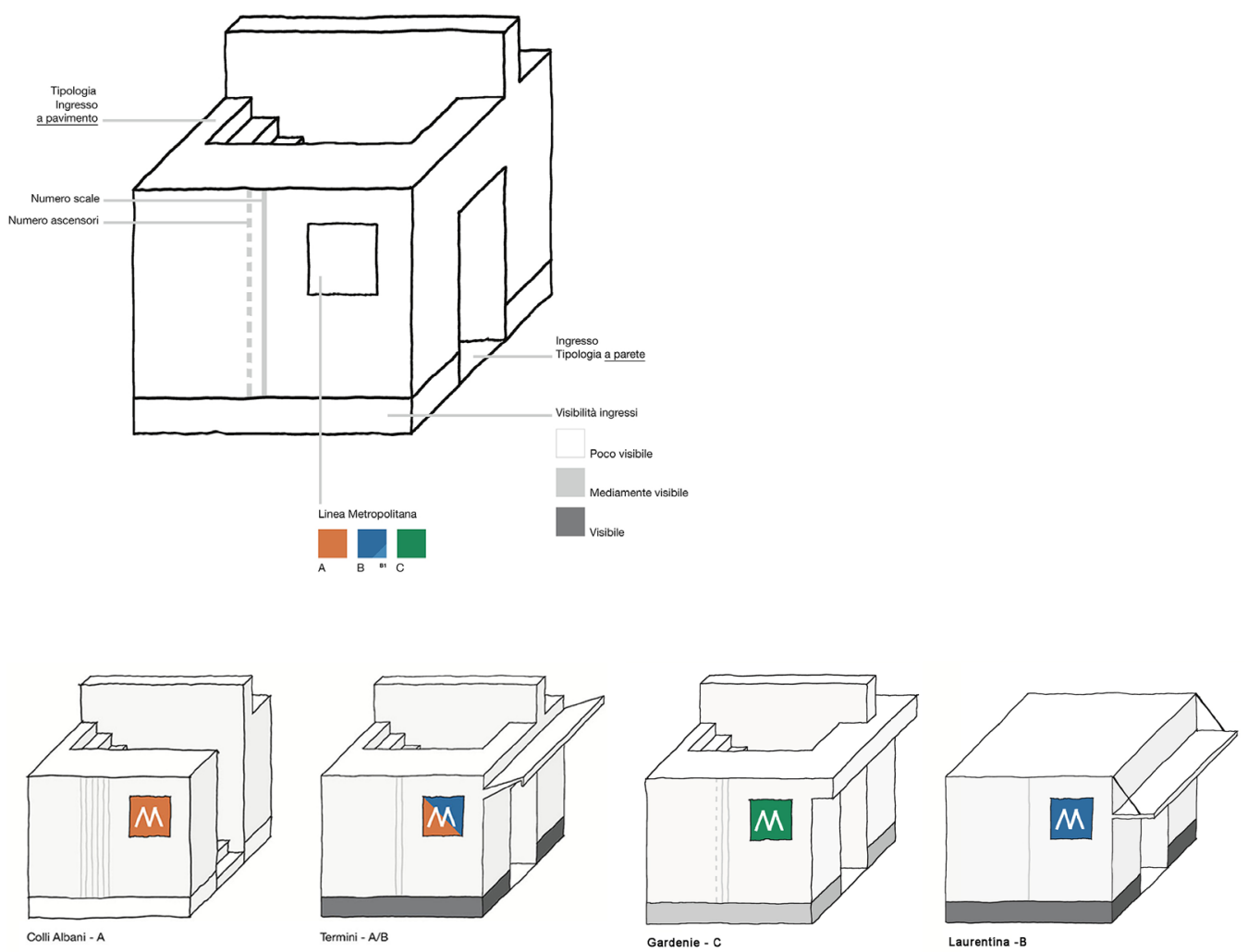

Fig. 7. Example of

composition relating to

the access of the Colli

Albani, Termini, Castro
Pretorio, Teano stops

Fig. 8. Example of

composition relating

to the access of the

Gardenie, Laurentina, San
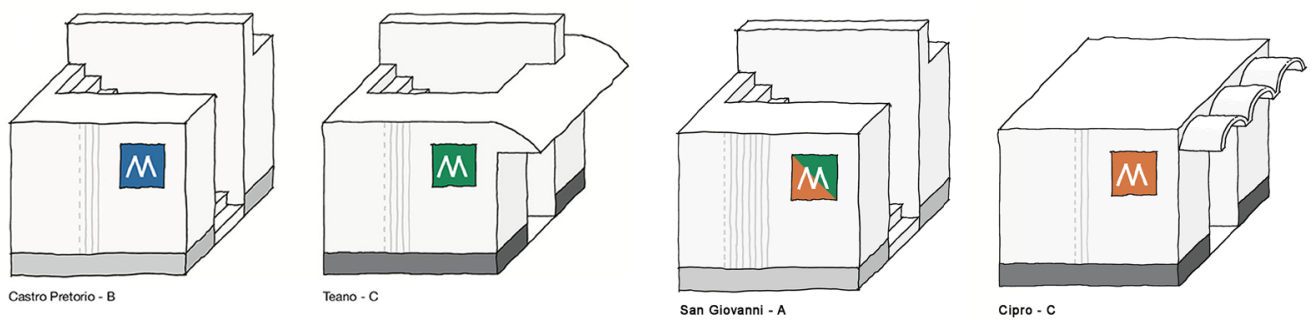
The Drawing provides for declinations of infinite graphic possibilities which, read in their entirety, identify a narrative text.

The manipulation of the cube-object, starting from a regular grid, makes use of reiterations and variations. It is an operation that advances by tests, by attempts, by experiments and by juxtapositions. It has a procedural and constructive connotation [Purini 20 I0, p. I2].

Fig. 9. Giorgia Lupi, The Digital in Architecture. Image taken from: <www. giorgialupi.com $>$ (accessed 2020, December 5)

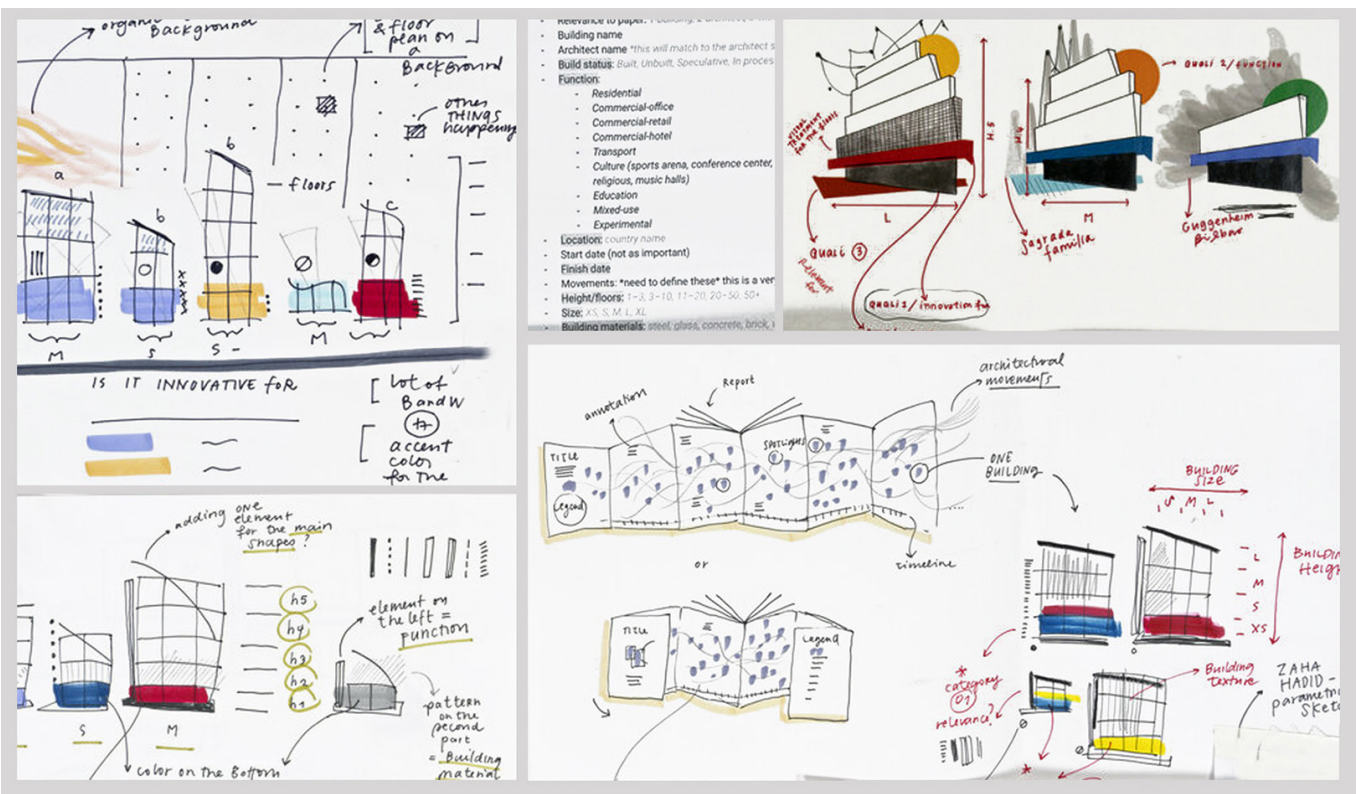

The images, once in sequence, vary little, of that slight variation that, however, makes them unique and different, so the invention of the form proceeds with a work on discrepancy and discord.

The graphic composition, while based on expressive freedom (and still maintaining a level of abstraction), was conducted through a conformative matrix that generated a range of configurations.

The morphogenesis process started with a regular geometric grid to identify the surfaces and volume of the cube (fig. 6). The geometrization is aimed at controlling the parts that underlie the internal composition of the design process.

The creative itinerary is built on ideation and rule, on invention and transgression, structuring the form from time to time according to the information that it must manifest [Cervellini 2020, p. 204]. The composition has incorporated in itself the parameters selected previously. The type of access was identified with a plastic action in the cube (stair for access to the floor, door for access to the wall). The other data was defined on the surfaces of the cube. The metro line is made explicit through the " $M$ " symbol with its official color of belonging. The number of stairs and lifts was specified by means of continuous and dashed vertical lines, while the greater or lesser visibility was specified by means of a band with different shades of grey. An additional volumetric element to the cube identifies the presence or absence of an external canopy (figs. 7, 8).

This work of synthesis of information, often overlapping, has led to three-dimensional objects that only vaguely want to recall an architecture. We started from an important reference such as The Digital in Architecture by Giorgia Lupi (fig. 9), a work in which the data relating to digital-oriented buildings are remodelled in proto-elevations of architectures, demonstrating how it is possible to create graphic elaborations in which design and data are closely connected [Lupi, Posavec 20 I 6, p. 22; Lupi, Posavec 20 I0, p. I 4]. 
The latter example shows us two-dimensional objects, therefore, much easier to control than a third dimension. Even in Lupi's sketches, we see that the idea of three-dimensionality is then abandoned. Taking them as an example, we worked on discretizing the data collected in the inspections to insert them within a volume that had its own coherence but without excessive complexity. In fact, the goal was to arrive at a 'Wide Drawing'. Referring to the splendid work of the Chilean duo Pezo Von Ellrichshausen for the Biennale of Chicago, (fig. 10) an attempt was made to compose the set of volumes, with minimal and fundamental variations, within a composition as vast and regular as possible.

In this way, it was possible to embrace a large amount of data, offering both a coherent and understandable overall picture but also an image that can be interrogated and consulted by going into detail.

Fig. 10. Mauricio Pezo and Sofia Von Ellrichshausen, Serial sequence of an imaginary building. Chicago Architecture Biennale 2017. limage taken from:

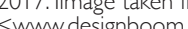
com $>$ (accessed 2020 December 5).

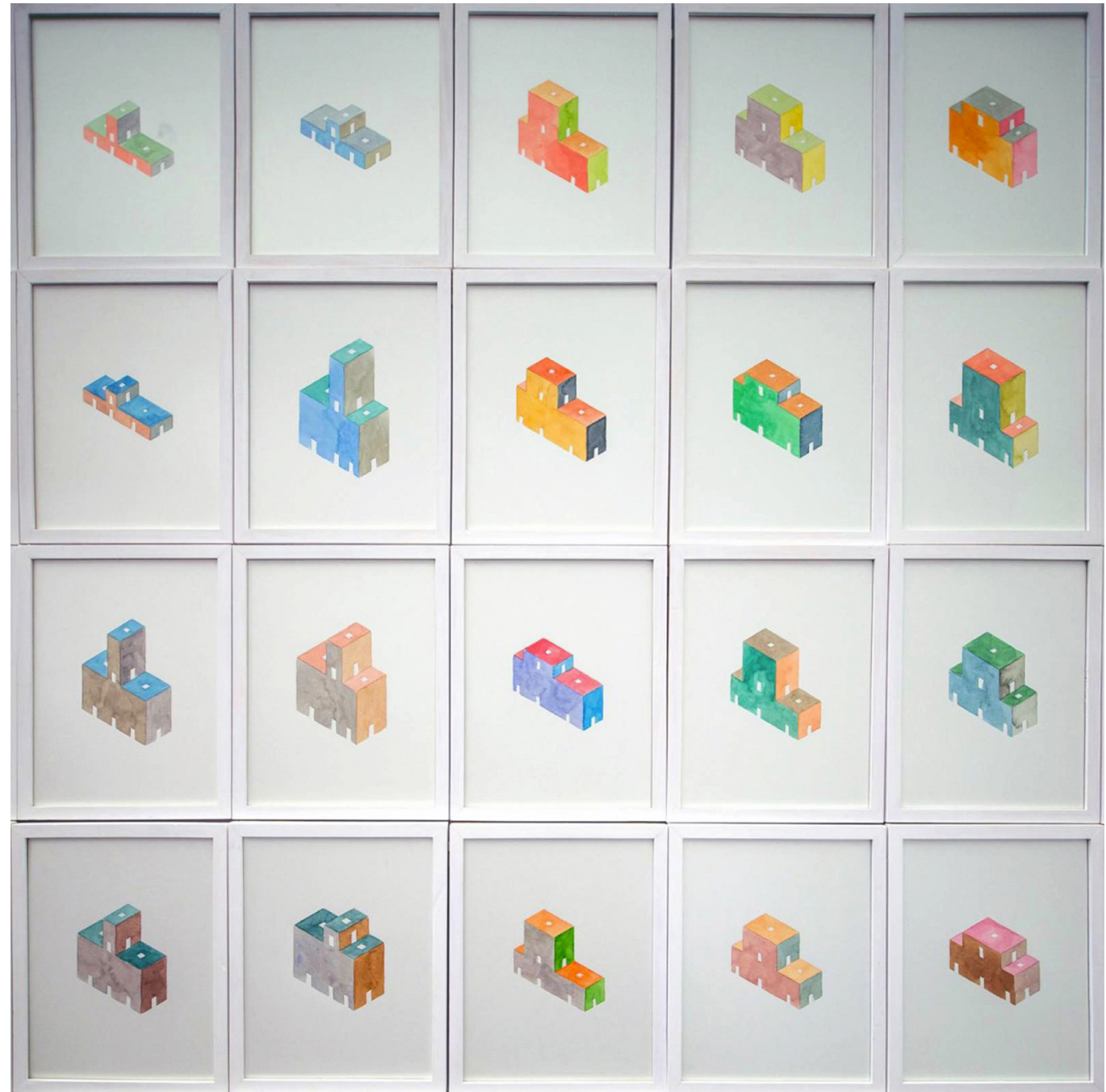

\section{Conclusions}

Faced with this series of small volumes designed to depict the entrances to the Rome subway, the eye can embrace the whole or get lost within the numerous variants. By embracing the whole, you immediately have a perception that allows you to grasp some obvious situations, such as the number of stations. Trivially, even visually realizing how many Metro stations exist for each line is information that is often not very clear.There are 73 stations 


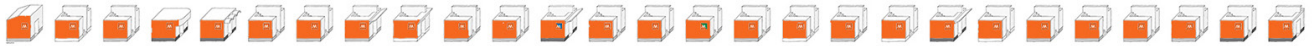 MA

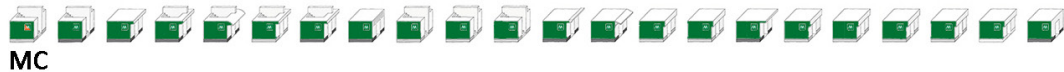

(fig. I I), with only three junctions to change lines. At the same time, having the legend in mind, one immediately realizes the poor visibility compared to the city that Metro A possesses when compared to its two younger sisters; certainly, because metro $B$ and $C$ are of more recent construction.

If, on the other hand, we approach the individual volumes, we can grasp other details, namely the type of access present in each station (wall, floor, or both), but above all, the number of stairs and elevators that allow access to the Metro. Through a quick work of comparison,

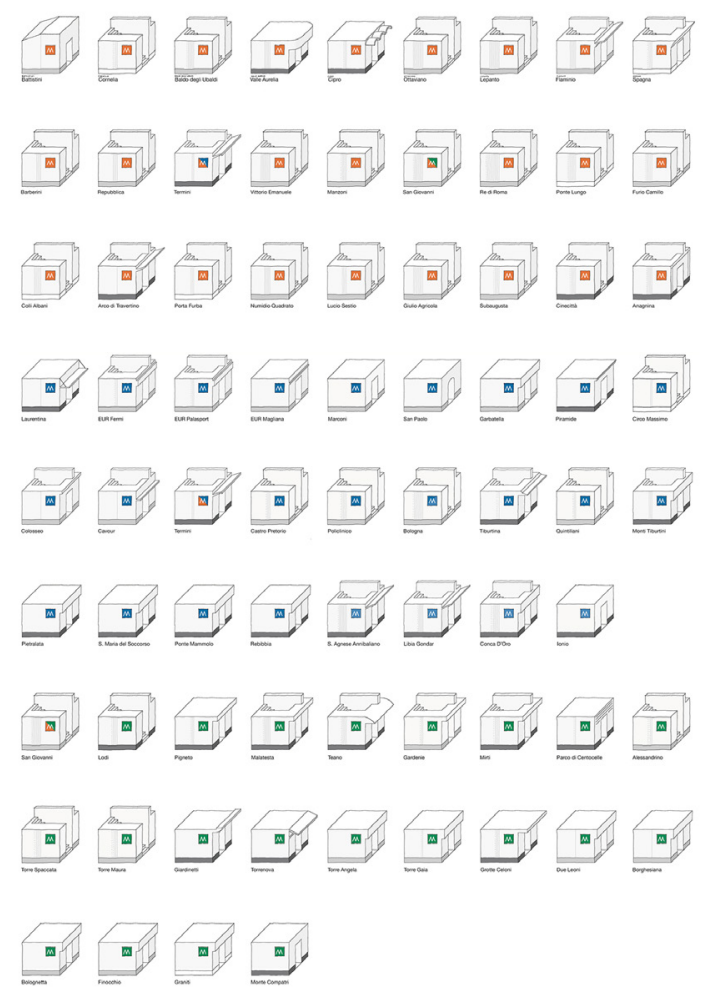

we immediately realize the almost absence of lifts on line A (centre of severe controversy in various municipalities), but also of the regularity of wall accesses for some sections of metro $B$ and $C$.

The interpretations are multiple, and the three-dimensional volumes in this step of the research are presented in their most elementary conformation. In the future, there will be the possibility to integrate information to have an overall picture as complete as possible. This 'Wider Drawing', therefore, allows the viewer to embrace even divergent information by framing them within a predefined, but at the same time flexible, scheme. Interfacing with the information and critical issues that the Rome metro presents, therefore, becomes a visual issue first of all, with the hope of a future adaptation of each access to the Universal Design rules, or to changes to the different accesses for easier use for citizens and tourists (fig. 12) [I]. 


\section{Notes}

[I] Emanuela Chiavoni wrote Abstract, Introduction, The wider drawing. Sara Colaceci wrote Methodology and Experimentation. Federico Rebecchini wrote Experimentation and Conclusions. Graphic elaboration by Federico Rebecchini.

\section{References}

Augé M. (2009). Nonluoghi. Introduzione a un'antropologia della surmodernità. Milano: Elèuthera.

Cervellini F. (2012). I modi del disegno d'invenzione. In Disegnare. Idee immagini, anno XXIII, n. 45, pp. 56-65.

Cervellini F. (2020). II Disegno officina grammaticale della Forma visiva. In G. Aureli, F. Colonnese, S. Cutarelli (a cura di). Intersezioni. Ricerche di Storia, Disegno e Restauro dell'Architettura, pp. 203-2 I0. Roma: Artemide.

Fachinelli E. (1983). Claustrofilia. Saggio sull'orologio telepatico in psicoanalisi. Milano: Adelphi.

Fachinelli E. (1988). Estasi metropolitane. In M. Manzoni, S. Scalpelli (a cura di). Velocità. Tempo sociale tempo umano. Milano: Guerini e Associati, pp. I13-1 6

Fachinelli E. (1989). La mente estatica. Milano: Adelphi.

Ippoliti E. (20 I7). Rinnovare lo sguardo. II disegno e le sue pratiche: rappresentare, comunicare, narrare. In Diségno, I, pp. I 43 - I 54.

Lupi G., Posavec S. (20 I0). Observe, Collect, Draw! A Visual Journal. Hudson: Princeton Architectural Pr.

Lupi G., Posavec S. (20 I 6). Dear Data. London: Particular Books.

Purini F. (20 I0). Un quadrato ideale. In Disegnare. Idee immagini, anno 21, n. 40, pp. $12-25$.

\section{Website}

<https://www.storiadeldisegnografico.com/2020/03/I7/information-design-i-pionieri/> (accessed 2020, December I2).

<http://giorgialupi.com> (accessed 2020, December I5).

<http://densitydesign.org/> (accessed 2020, December 15).

<http://www.lbollini.it/> (accessed 2020, December I5).

\section{Authors}

Emanuela Chiavoni, Sapienza Università di Roma, emanuela.chiavoni@uniromal.it

Sara Colaceci, Sapienza Università di Roma, sara.colaceci@uniromal.it

Federico Rebecchini, Sapienza Università di Roma, federico.rebecchini@uniromal.it

To cite this chapter. Chiavoni Emanuela, Colaceci Sara, Rebecchini Federico (2021). Un disegno più vasto. Linguaggi, distanze \& psicologie/ A Wider Drawing. Languages, Distances \& Psychologies. In Arena A., Arena M., Mediati D., Raffa P. (a cura di). Connettere. Un disegno per annodare e tessere. Linguaggi Distanze Tecnologie. Atti del $42^{\circ}$ Convegno Internazionale dei Docenti delle Discipline della Rappresentazione/Connecting. Drawing for weaving relationship. Languages Distances Technologies. Proceedings of the $42^{\text {th }}$ International Conference of Representation Disciplines Teachers. Milano: FrancoAngeli, pp. 452-471. 